\title{
Price and Profit (Conventional and Islamic Analytical Perspectives)
}

\author{
Desi Ika $^{1}$, Yani Suryani ${ }^{2}$ \\ ${ }^{1,2}$ Universitas Harapan, Medan, Sumatera Utara, Indonesia \\ Corresponding Author: Desi Ika
}

DOI: https://doi.org/10.52403/ijrr.20220219

\begin{abstract}
The commodity price reflects its value or its exchange rate compared to other commodities. Based on the producers' point of view, price is a commodity value which brings profit to the company. On the other hand, consumers see price as the value of commodities, both goods and services that can be useful for their daily needs. The role of the Government as a price maker is carried out through direct and indirect intervention. Although in Islam there are no provisions that regulate how much traders or producers may take profits, they are required to be reasonable in raising prices so as not to oppress consumers. Even if this happens, the government has a role on controlling the price through some policies. Producers and traders can get profit as long as their activities do not violate Islamic norms. The market mechanism, the balance of supply and demand forces, is the most important principle in the process of determining commodity prices in the concept of Islamic teachings. It happens when there is willingness among economic actors. Determination of profit and rational behavior for profit maximization in Islamic teachings is principally driven by three factors, namely assuming that business is fardhu kifayah, protection of consumer interests and profit sharing.
\end{abstract}

Keywords: Price, Profit, Islamic Teachings, Conventional

\section{INTRODUCTION}

\section{A. Background}

Price is the most frequently discussed topic in economics field which reflects the comparative value among commodities. Economy is the main driven power to bring society in a prosper life. Country's power lays on the fact that how proper the policies in that country in stabilizing the price. In reality, it is not an easy task since demand and supply are rarely equivalent.

On the other hand, pricing is done to get maximum profit because it's the entity's main objective in a business. Nevertheless, the linkages between economic actors, including the government, are certainly necessary in order to achieve welfare for the society as a whole. It also applies on determining price which involves all actors in order to minimizing fraud and losses that may occur to a certain party. In this case, the government has full responsibility on determining commodity prices because the government has a legal authority on pricing. Islam has syariat on its ummat in doing muamalah. In Islam, pricing must be free from the element of usury.

\section{LITERATURE REVIEW}

\section{A. The Definition of Price}

The commodity price reflects its value or its exchange rate compared to other commodities. Based on the producers' point of view, price is a commodity value which brings profit to the company. On the other hand, consumers see price as the value of commodities, both goods and services that can be useful for their daily needs. In a perfectly competitive market, the prevailing product price comes from an agreement 
among consumers and producers. In fact, this ideal situation rarely occurs in the market. Mostly, producers have more power on determining the product's price. Apart from these actors, other parties such as competitors, suppliers, distributors, trade associations and the government also have plausible effect on determining product's price.

\section{B. Theoretical framework}

Understanding the price theory, there are points that must be known such as the price function where the product's price can act as a source of income or profit, balancing the level of demand and supply. In addition, prices also affect distribution and other sectors of business activity. Determination of product's value can be affected by external and internal factors. Price changes are limited by competitors, costs and demand. Prices will fluctuately move along with the competitors' power in the market. The role of the Government as a price maker is carried out through direct and indirect intervention.

\section{The Definition of Profit}

Profit is the difference between total revenue and expenses incurred by the entity for a certain time. Profit is used as the basis of dividend policy, tax calculation, investment and most importantly for the process of making decisions and forecasting the future of the entity. Understanding profit in economics is not exactly the same as profit according to accounting science, where profit in economics is defined as an increase in company wealth. Meanwhile, profit in accounting is the difference between income and costs or capital spent in certain period. Gains and losses are often used as a standard in measuring an entity's financial performance.

\section{Earnings Management}

Earnings management can be interpreted as management behavior in managing or manipulating the amount of profit earned by the company. On the other hand, earnings management means presenting the information in the financial statements which can be very deceptive for the targeted parties yet beneficial for the managers. Although this does not violate generally accepted accounting principles, in the long term it is lowering public trust in the company's financial statements and hindering the capital inflow from the stock market. Management behavior in manipulating profits earned in a certain period will cause an increase or decrease in the long-term profitability of the entity as a whole.

\section{MATERIALS \& METHODS}

This research used the descriptive analytical method. Descriptive analytical method is used to analyze the research findings but the results cannot be generalized for all population.

\section{RESULT}

\section{A. Pricing: Secular Point of View}

Maximum profit is the entity's main objectives to be achieved by determining the selling price of the commodity. Here are some approaches that can be taken:

1) Close plus pricing, determining the value of the product through the addition of a certain amount of the selling value of the product as well as the costs incurred into profit.

2) Mark-up pricing, determining the value of the product through the addition of a certain amount of the selling value of the product or its capital.

3) Break even analysis, is to determine the selling value where income is equivalent to the capital. Through understanding the break-even limit, prices can be set above it in order to make a profit.

4) Maximum profit, determining the maximum profit margin.

There are several strategies applied in pricing, namely:

a. Demand-focused pricing strategy

b. Competitive pricing strategy 


\section{B. Pricing Based on Islamic Teachings}

In Islamic teachings, the mechanism for determining the selling price must follow the principles of Maqashid Syariah, where this guideline will create prosperity and avoid human misery. The most basic principle is that prices are determined by the mechanism of the power balance between supply and demand. This can be achieved if the buyer and seller are mutually agreed. Pricing in the view of Islam is guided by the principles of willingness, fairness, honesty, and transparency.

\section{Profit in Secular Point of View}

Profit is the most attractive part for the investors in which it represents the company's performance as a whole. Unfortunately, accounting theory has not yet reached a general agreement on the meaning and measurement of earnings. Based on the conventional accounting concept, profit is reported as the information of company's economic value and its management although different users have different objectives. Profit maximization in secular economic studies generally uses impersonal mechanisms for its distribution. This mechanism is mainly based on the market mechanism. Employee's rights will be included as production costs which will eventually eliminate the rights of the employee.

\section{Profit in Islam}

Profit can be interpreted as additional money or income obtained from trade transactions. Profit is sometimes linked to the commodity itself. In a more measurable way, profit in the context of trading is the additional value obtained from the margin between the commodity's purchase price and the selling price. Determination of profit maximization and its rational behavior in Islamic teachings is principally directed by three factors:

1. Assuming that business is fardhu kifayah

The ownership is limitless, including profit, in all business activities. The things that are regulated are the mechanism on gaining the profit and its use because they are related to halal and haram regulations.

\section{Protection of Consumer Interests}

Protection of the consumers' interests is an action related to all possible losses that are felt by consumers. It might occur from the beginning until the end of the transaction. In Islamic teachings, it is forbidden to deceive consumers.

\section{Profit sharing.}

The profit-sharing system has a potential on increasing efficiency, equity and stability in production. This system prevents business actors from being greedy.

\section{E. Ethics in Gaining Profit}

Profit is always the business' main objective. Nevertheless, sometimes we neglect business ethics, which ultimately leads to an attitude of getting as much profit as possible by ignoring others' interests. The real motivation in doing business is not only seeking profit, but also helping other people in need. The intention to get a large profit will have an effect on the traders' behavior which tends to be negative, such as lying, taking advantages, manipulation, cheating, swearing, and others. Trading practices must be free from manipulation and fraudulent actions. Islam strictly prohibits offers that can divert the attention and interest of buyers that can harm consumers. Although Islam does not provide definite standards relating to profit taking in buying and selling, taking unusual profits are not allowed. This is certainly burdensome to the consumer. Islam does not forbid taking profit, but must remain within the reasonable state.

\section{DISCUSSIONS}

The maximum profit - oriented which legalizes all methods is against the teachings of Islam. However, there is a dogma which says that humans should strive for the happiness and glory in the hereafter as well as in this world. It seems to be the 
motivation that encourages Muslims to earn profit, including profits in business. So the theory of profit maximization is actually needed within the framework of Islamic economic theory.

Secularism maintains the assumption of profit maximization even though its character is unrealistic and even misleading, mainly for two reasons: First, price theory, which is the core theory of economics, cannot stand upright after the maximization assumption is abolished. Second, these critics have so far been unable to propose an alternative code of conduct that can have the same value, which is predictive and leads to conclusions that can be empirically tested. The concept of profit is the core issue, and the important factor is the paradigm framework of the economic system being studied. To create a reasonable conclusion, nature of profit and its maximization under the existing systems: the secular system and the Islamic system should be evaluated.

Products are the combination between several economic factors, capital (which also includes land), labor and other required production factors. This combination of several factors of production will provide the desired output for producers. In this process justice must be found, where how much these factors of production contribute to the formation of output. Secular economic theory - in this case - generally takes an impersonal approach in terms of distribution. This impersonal approach is based primarily on market mechanisms.

Meanwhile, Islamic teaching uses an 'instructional approach' in distribution. In fact, Islam considers profit as the total value of the commodity minus depreciation and the minimum wage which must be distributed among workers and business owners on the basis of justice. The scheme is seen as a better offer and will bring a distribution mechanism closer to the norm of justice than pure market arbitrage. Thus, interest does not have a place in this Islamic scheme. There are some criticisms of the above formulation from the Islamic point of view on profit. In the following section, the answers or criticisms will be presented on this problem.

Maximizing profits is considered to have nothing to do with individual welfare when viewed from a capitalist or secular economic study. Smith stated that "the pursuit of self-interest can automatically increase the collective good in a free enterprise system," is believed to complement the notion of greater social respectability. In the classical model, entrepreneurs are always competing for personal profit in an open industry. Perfectly competitive market in the sense that individual buyer has no power to set prices in the market with two aspects of social welfares.

First, allowing entrepreneurs to take a rate of return from their capital which is not more than sufficient to give them an absolute income, which consists of: (1) interest on investments in non-losing securities; (2) salary for the services they have provided to the company in relation to management as measured by opportunity cost; and (3) the premium for risk taking as determined based on the actuarial estimate. This means that competitive pricing provides the employer with a normal level of profit, which, as such, is considered a legitimate reward for the productive employees and should be treated as production costs.

Second, self-enrichment directed by competition also maximizes the product as optimal enterprise utilization in each case. Furthermore, each factor can be demonstrated to earn what it contributes to the company's product value as gains at the scale of the company under fixed assumptions. The model was criticized for being very unrealistic. Its real significance is to show that the model destroys itself, even though the initial situation is the same as described, and that normal profit need not remain destructive in the process. The argument of this model ignores an important nature of profit. 
The process of multiplying profits must depend on perfect competition situation with. If the company's sales are growing in this way, then its capital must be increased proportionally. The normal interest component of earnings will increase by the same ratio. However, managerial concerns are expected to increase in less proportion to the company's production activities. Risk of losing actually tends to decrease when the business becomes large and stable. Even if it increases, it is unlikely to increase in the same ratio, as in sales. Thus, the increase in the income of the entrepreneur coincides with the doubling of sales. This rarely occurs commensurate with an increase in risk-taking or managerial effort, although the return on capital may still appear 'normal'. The exaggeration conclusion leads to the quantity is constant and cannot be divided relative to the size of the firm.

The doubling of sales creates imperfect competition, but it clearly shows the great side of modern business. The business's main important aspect is that of profit as a surplus over costs (and taxes). The concept attracts entrepreneurs to pull as far as possible the prices of sales and purchases in order to enrich themselves. The price maximization hypothesis provides support and rewards for this statement. Absolutely, entrepreneurs initiate actions both in product markets and other factors to overcome competition and create monopolistic shelters in order to increase the size and continuity of their profits.

The tendency to act monopolistically has certainly played a role in the great institutional and technological transformations that have taken place in market economies over the centuries. Two consequences of this transformation may already be known, including: (1) the rise to dominance of large corporations which has disintegrated the entrepreneur's personality into obscurity through the separation of ownership in management and the decentralization of decision-making actions along the hierarchy in modern companies.
(2) The monopolistic market structure has become an integral part of a free market economy. In a monopolistic competition, the exploitation of workers and consumers tends to increase with the emergence and expansion of 'abnormal - profits. Maximizing profit as a business goal is a widely known notion yet brings lots of conflicts. However, this conflict can be minimized if the profit concept is based on a sharing method.

\section{CONCLUSION}

The commodity price reflects the exchange rate value with other commodities. From the producer's point of view, price is a commodity value which brings profit to the company. Meanwhile, consumers see that price is the value of commodities, both goods and services that can be useful for their daily needs. The government's role as a price maker is carried out through direct and indirect intervention.

Although in Islam there are no provisions that regulate how much traders or producers may take profits, they are required to be reasonable in raising prices. Hence, consumers are not being oppressed. Even if it happens, government has a role in stabilizing the price in the market. Producers and traders can take advantage of certain amount as long as their activities do not violate Islamic norms. The market mechanism, the balance of supply and demand forces, is the most important principle in the process of determining commodity prices in the concept of Islamic teachings. There should be an element of willingness among economic actors.

Profit is the difference between total revenue and costs incurred by the company at a certain time. Profit in the financial statements can be used as a basis on determining dividend policy, tax, investment and most importantly are making decisions and forecasting the entity's future. Earnings management can be interpreted as management behavior in managing or manipulating the amount of profit earned by the company. Earnings 
management sometimes is about presenting reports that may deceive interested parties in the financial statements, but solely beneficial for managers' interests.

\section{Acknowledgement: None}

\section{Conflict of Interest: None}

\section{Source of Funding: None}

\section{REFERENCES}

1. Asy-Syurbashi, Ahmad. (1981). Almu'jam al Iqtisad al-Islamiy. T.tp.: Dar al-Jail.

2. Fauzia, Ika Yunia. (2014). Prinsip Dasar Ekonomi Islam Perspektif Maqashid AlSyariah. Penerbit Kencana Prenadamedia Grup. Jakarta

3. Fatoni, Siti Nur. (2014). Pengantar Ilmu Ekonomi (Dilengkapi Dasar-Dasar Ekonomi Islam). Pustaka Setia. Bandung

4. Hakim, Lukman. (2012) Prinsip-Prinsip Ekonomi Islam. Penerbit Erlangga.
5. Harahap, Isnaini Yenni, dan Samri Juliati Nasution. (2015). Hadis-hadis Ekonomi. Kencana. Jakarta

6. Mankiw, Gregory. (2003). Pengantar Ekonomi. Erlangga. Jakarta

7. Rahmawaty, Anita. (2011). Ekonomi Mikro Islam. Nora Media Enterprise. Kudus

8. Sudaryatmo. 1996. Masalah Perlindungan Konsumen di Indonesia. Citra Aditya Bakti Bandung

9. Sugiyono. (2005). Metode Penelitian Bisnis. Alfabeta. Bandung

10. http://repo.iaintulungagung.ac.id/6407/8/bab 8_Maksimalisasi_laba_islam_rokhmat_ok_ book_antiq_arab.pdf . Diakses 12 Februari 2019

How to cite this article: Desi Ika, Yani Suryani. Price and profit (conventional and islamic analytical perspectives). International Journal of Research and Review. 2022; 9(2): 131-136. DOI: https://doi.org/10.52403/ijrr.20220219 